\title{
Symbiotic and Phenotypic Characteristics of Rhizobia Nodulaing Cowpea (Vigna Unguiculata L. Walp) Grown in Arid Region of Libya (Fezzan)
}

\author{
Mariam Abdelnaby ${ }^{1}$, Nazar Nasreldeen Babiker Elnesairy ${ }^{2}$, Salah Hassan Mohamed ${ }^{1}$ and Youness Abubaker Ali \\ Alkhayali ${ }^{1}$ \\ 1. Department of Botany, Faculty of Sciences, Sebha University, Sebha 21871, Libya \\ 2. Department of Soil and Water, Faculty of Agriculture, Sebha University, Sebha 21871, Libya
}

\begin{abstract}
Symbiotic and phenotypic characteristics of thirty rhiobial isolates obtained from root nodules of two cowpea (Vigna unguiculata L. Walp) cultivars that grow in different sites of Fezzan (Southern part of Libya) were studied. Cultural characteristics and cross-nodulation with Arachis hypogega and Faidherbia albida showed that they were slow-growing rhizobia. Each isolate was found to coexist with non-symbiotic bacteria similar in their cultural characteristics to fast-growing rhizobia. All isolates formed symbiosis with the test plants, but different in their nitrogen-fixation efficiency. Numerical analysis of phenotypic characteristics showed that at boundary level of $70 \%$ average similarity, the isolates formed four distinguished groups and two isolates remained separate. Most isolates exhibited wide tolerance to acidity, alkalinity and extreme temperatures. They also resistant to some heavy metals such as mercury, copper, zinc, lead, cadmium and aluminum at low concentrations and antibiotics like polymyxin, colistin, bacitracin and nalidixic acid. Isolates displayed different response to salinity ranging from sensitive, which unable to grow in $1 \% \mathrm{NaCl}$ to resistant and grow at $2 \% \mathrm{NaCl}$ or above. Urea was hydrolyzed by most of them and carbohydrates utilizations were different. Sucrose and maltose were metabolized by most of the test isolates, whereas, monosaccharide and sugar alcohols were poorly utilized.
\end{abstract}

Key words: Libya, Fezzan, cowpea, phenotypic, rhizobia.

\section{Introduction}

Cowpea (Vigna unguiculata L. Walp.) is popular food grain legume in Africa, playing an important role in economy of many African countries. The annual global production is estimated over 3 million tons [1]. Cowpea is adapted to heat, drought and low-nutrient environment. Therefore, it is cultivated in arid and semi-arid regions as a source of food, forage plant and sustains soils. Another important characteristic of cowpea is their abilities to form symbiotic association with soil bacteria known as rhizobia to form nodules where the atmospheric nitrogen may fix. Therefore, increases and maintain soil fertility. In some countries

Corresponding author: Salah Hassan Mohamed, Ph.D., research field: soil microbiology (rhizobiology). E-mail: salahhassan46@yahoo.com. of Africa, cowpeas are used to increase productivity of the cereal crops and used as a part of the rotational crops, cultivated intercrops, in rotation or as independent crops [2]. Criteria for characterization of rhizobia were proposed [3]. These Criteria include phenotypic and molecular methods. Traditional methods include cultural, physiological and biochemical tests. Earlier, phenotypic study was used by some researchers [4-6] to characterize rhizobia from different legumes which now used as complementary to molecular methods [3]. In addition, phenotypic studies are useful for selection of superior rhizobial strains adapted to environmental stresses such as salinity, acidity and elevated temperatures [7]. Molecular methods include PCR-based fingerprinting methods such as $16 \mathrm{~S}$ rRNA gene sequences, DNA-DND hybridization and DNA-rDNA 

Grown in Arid Region of Libya (Fezzan)

hybridization. At present, rhizobia consists of more than one hundred species belongs to the genera: Rhizobiumand, Bradyrhizobium [8], Ensifer [9, 10], Mezorhizobium [11], Allorhizobium [12], Azorhizobium [13], Methyobacterium [14], Devosia [15], Cupriavids [16] and Shinella [17].

Rhizobia nodulating cowpea were long reported as slow growing categorized into "cowpea miscellany" group [18] which is heterogeneous group of rhizobia nodulating tropical legumes such as Arachis hypogaea, Macroptilium atropureum and Phaseolus lunatus. However, it is currently classified into genus Bradyrhizobium [8, 19]. Phenotypic and genetic studies of cowpeas rhizobia were aim of researchers in some parts of Africa [20-26]. Contradictory reports about the microsymbionts of these plants were reported. Some investigators indicates that cowpea nodulated by both fast and slow growing rhizobia [20-24]. Analysis of 16S rRNA gene sequences of fast-growing nodule occupancy showed that they are similar to coliform bacteria (Enterobacter, Klebsiella) and Rhizobium, while, the slow-growing one is close to Bradyrhizobium genus [24]. Others [25, 26] only revealed the presence of slow-growing rhizobia related to B. Alkanii and B. japonicum which had cross nodulation with Faidherbia albida Nevertheless, the diversity of cowpea rhizobia is more diverse in arid regions [25, 27]. Some researchers related this diversity to geographical origin [23], which differs in the environmental characteristics like soil type and $\mathrm{pH}$, temperature, climate and moisture. Nerveless, characterizations of these rhizobia are limited, mostly restricted to tropical and subtropical areas of Africa and have not been characterized in many areas [28]. The contradiction reports about the symbiosis between cowpeas and rhizobia could be solved by more studies and characterization of cowpeas rhizobia in different geographical regions.

Libya is one of the North African countries, large area located in arid desert area (Fezzan) with scattered oasis in which Libyans live and depends upon ground water. Environmental stresses like high summer temperature, salinity, drought, low soil fertility and wind are the major challenges that Libyan farmers face. Nevertheless, large area of land placed into cultivation and different legumes and cereal crops are cultivated. Cowpea is one of the earliest legume crop known to the inhabitants of Fezzan, it gains a wide popularity between small holders farmers in many oasis which used mainly as a source of protein. Their role in biological nitrogen-fixation is as other legumes in the region neglected. The aim of the present study is to isolate and phenotypically characterize the rhizobial isolates from different sites in arid region of Libya (Fezzan). Such study could increase the knowledge about the microsymbionts of cowpea rhizobia and select superior isolates for using as inocula. Thus, in order to improve soil fertility in arid region of Libya.

\section{Study Methods}

\subsection{Description of Study Area}

The study area included different locations of Fezzan (southern part of Libya) (Fig. 1). The demarcation of the Fezzan lies in the parallel of $22^{\circ} 30^{\prime}$ $\mathrm{N}$ and $30^{\circ} 00^{\prime} \mathrm{N}$ and between the meridians of $10^{\circ} \mathrm{E}$ and $18^{\circ} \mathrm{E}$. It is a huge sand flat interspersed with some dry mountains and valleys with scattered oasis in which Libyans are living and depends upon ground water. The desert climate is prevalent and there is a significant difference between the temperatures. In the summer, sometimes it can reach $46{ }^{\circ} \mathrm{C}$, while in winter, it drops to less than zero. Rainfall is scarce and does not exceed the annual average of $20 \mathrm{~mm}$. Groundwater is the main source for both drinking and irrigation systems. The water salinity is only 1.5 gram/liter [29].

\subsection{Nodules Collection}

Fresh and healthy root nodules were collected from two cowpea cultivars: indigenous and crowed pea (brown eye) and exotic (black eye) was collected from 
African coast zone (Mali). They grow in the field from four different locations in the Fezzan, Ghat, Sebha, Marzuq and Alshati (Fig. 1). These locations are separated from each other by a distance ranging of $200-400 \mathrm{~km}$.

\subsection{Isolation and Authentication of Root-Nodule}

\section{Bacteria}

The medium and method of isolation were as described earlier [30]. All isolates were tested for their abilities to produce nodules on the plant species from which they were originally isolated. Seeds of the cowpea (Vigna unguiculata L. Walp) were surface sterilized by treating with mercury chloride $(0.2 \%$ $\mathrm{HgCl}_{2}$ ) for 5 minutes, rinsed several times with distilled water and germinated in darkness on a plate of $1 \%$ water agar. After germination at room temperature, seedlings were aseptically transferred to test tubes containing sterilized Jensen medium [30]. After three days, each tube was inoculated with drop of log-phase culture (containing $10^{6}$ cells of each rhizobial isolate). Three replications were used for each isolate. Non-inoculated tubes were included and served as negative controls. After that, all tubes were transferred to wooden boxes and placed in the growth chamber. After four weeks of growth, the plants were examined for nodulation. Any isolates failed to form nodules were neglected.

\subsection{Cultural Characteristics}

\subsubsection{Time of Colony Development}

Log phase culture for each rhizobial isolate was streaked on yeast extract manitol agar (YEMA). The inoculated plates were incubated at $28{ }^{\circ} \mathrm{C}$ and daily inspected until a separate colonies developed.

\subsubsection{Acid or Alkali Production}

The ability of the rhizobia isolates to change the standard growth medium (YEMA) to an acid or alkaline was conducted as described earlier [5]. Plates containing yeast extract mannitol agar in which 0.025 $\mathrm{mg} / \mathrm{L}$ bromothymol blue indicator was incorporated, where each inoculated with $200 \mu \mathrm{L}$ in $\log$ phase

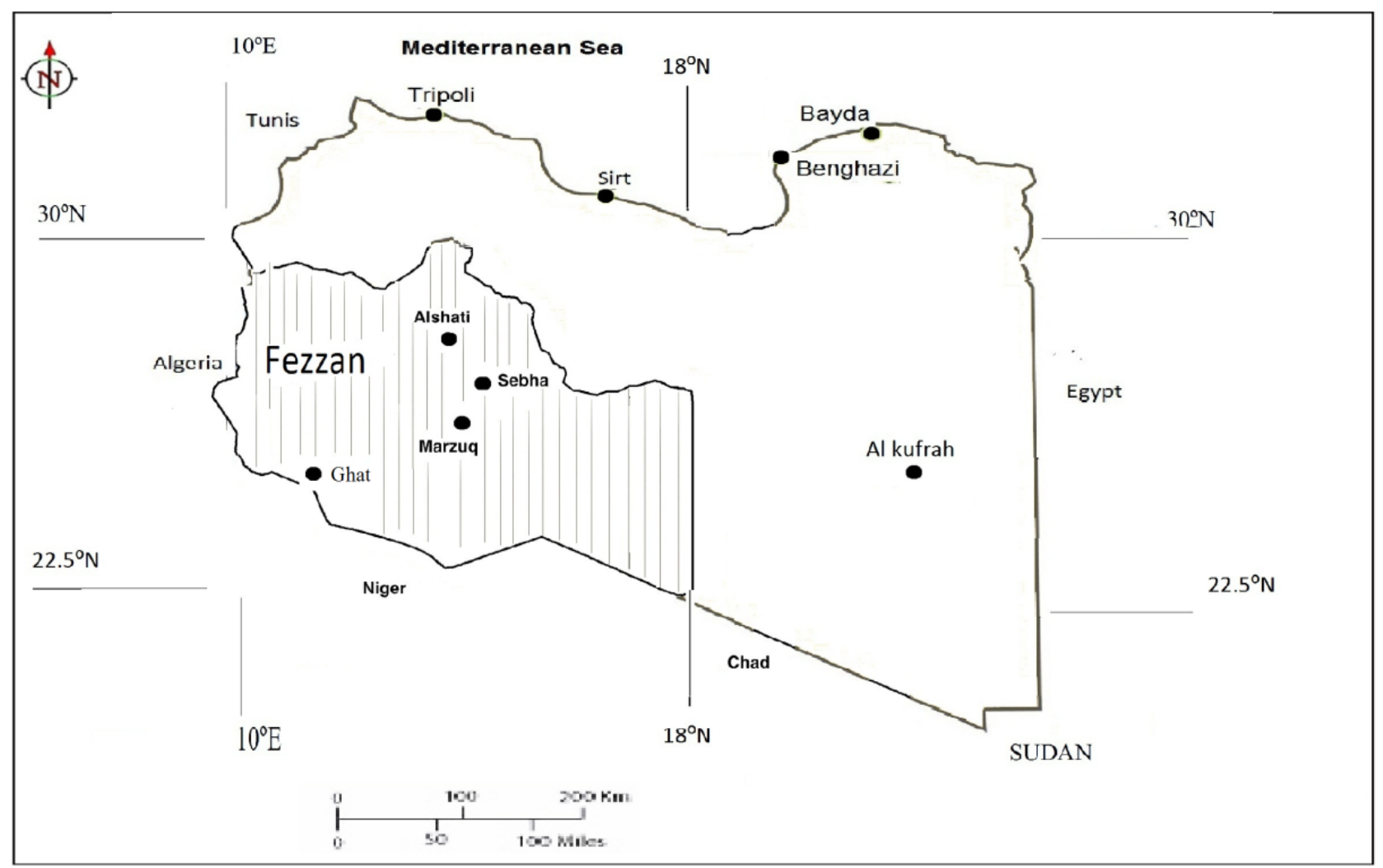

Fig. 1 Map of Libya showing the location of field collection of root nodules. 
culture of each test isolate and incubated at $28{ }^{\circ} \mathrm{C}$ for 10 days. When color change to blue around, the colonies was considered as alkaline production.

\subsection{Symbiotic Traits and Effectiveness}

The test of isolates were tested on two plants: Faidherbia. albida and Arachis hypogaea L., which usually nodulated by Bradyrhizobium strains as well as their host plant (Vigna unguiculata). Seeds of these plants were obtained from Mali. The method of seeds sterilization and inoculation of Arachis hypogaea L. and Vigna was as described above for the authentication of isolates, while seeds of F. albida were treated as described elsewhere [31]. Furthermore, surface sterilized and scarified with sulfuric acid were treated as stated above for other seeds, but incubation period was for eight weeks. After incubation period, all plants were examined for nodulation. A primary assessment of isolates to their abilities to fix nitrogen was made by comparing the color of inoculated plants with the control (uninoculated plants). Healthy and green plants were considered to be effective and ineffective if plants showed chlorosis [32].

\subsection{Physiological and Biochemical Characteristics}

With the exception of carbohydrate assimilation, temperature test, hydrolysis of urea and all other tests were carried out on YEM agar plates. Petri dishes containing (YEMA) medium were subdivided into four parts, each part was inoculated with $2 \mu \mathrm{L}$ of logarithmic phase of each rhizobial isolate. After 10 days of incubation at $28{ }^{\circ} \mathrm{C}$, bacterial growth was compared to the controls. Three replicates were used for each treatment.

\subsubsection{Growth Temperature}

Temperature tolerance was tested by incubating streaked plates at $42{ }^{\circ} \mathrm{C}$ and $44{ }^{\circ} \mathrm{C}$ for 10 days and inspected for colonies development.

\subsubsection{PH Tolerance}

Growth of test isolates at acid and alkaline $\mathrm{pH}$ was performed as previously described [33], but different on YEMA. The medium was adjusted with $0.1 \mathrm{~N} \mathrm{HCl}$ for acid and $0.1 \mathrm{~N} \mathrm{NaOH}$ for alkaline $\mathrm{pH}$ to the following range of $\mathrm{pH}$ before being autoclaved: $\mathrm{pH} 4$, pH 6, pH 8 and pH 10.

\subsubsection{Resistance to Heavy Metals}

The heavy metal resistance was determined as described earlier [4] on solid YEMA medium containing the following salts of heavy metal ( $\mu \mathrm{g} / \mathrm{mL}): \mathrm{AlCl}_{3} \cdot 6 \mathrm{H}_{2} \mathrm{O}(100,200,300$ and 500$), \mathrm{HgCl}_{2}$ (30 and 40$), \mathrm{Pb}\left(\mathrm{CH}_{3} \mathrm{COO}\right)_{2}(500), \mathrm{CuCl}_{2} \cdot 2 \mathrm{H}_{2} \mathrm{O}$ (100), $\mathrm{CdCl}_{2} \cdot 2 \mathrm{H}_{2} \mathrm{O}(20), \mathrm{ZnCl}_{2}$ (100) and $\mathrm{NiCl}_{2}(100)$.

\subsubsection{Intrinsic Antibiotics Resistance}

The test of intrinsic resistance to antibiotics was determined by using antibiotics discs (Oxoid) on the solid YEMA medium. The following antibiotics were used $(\mu \mathrm{g})$ : Penicillin (60), Streptomycin (10), Erythromycin (15), Tetracyclin (30), Vancomycin (5), Chloramphenicol (10), Colistin (10), Rifampicin (5), Ampicillin (10), Bacitracin (10), Nalidixic acid (30), Kanamycin (30), Polymyxin (30) and Gentamicin (10). After incubation, the plates were inspected for the presence or absence of inhibition zone around the discs.

\subsubsection{Salt Tolerance}

Tolerance to salinity was determined on YEM agar plates containing $0.5 \%-4 \%(\mathrm{w} / \mathrm{v}) \mathrm{NaCl}$.

\subsubsection{Hydrolysis of Urea}

This test was conducted on yeast extract-manitol medium containing 2\% (w/v) urea and $0.012 \%$ Phenol red indicator. Every dish containing this medium was inoculated with $200 \mu \mathrm{L}$ of actively growing test culture and then incubated at $28{ }^{\circ} \mathrm{C}$ for 10 days. Appearance of a red color indicated that the urea was hydrolyzed [34].

2.6.7 Carbohydrate Assimilation

Utilization of various carbohydrates (D-Glucose, D-Fructose, Galactose, Maltose, Sucrose, Lactose, D-Mannose, Truloese, Cellulose, Starch, Sorbitol D-Fruttosol and Inositol) was tested as reported before [33] on YEM agar. Yeast extract was replaced by $1 \%$ ammonium chloride and manitol by the test sugar. 
Medium containing manitol was used as a positive control and the medium without any carbon source as negative control. Each Petri dish containing this medium was as mentioned above, subdivided into sectors and each sector was inoculated with test isolate growing in logarithmic phase. All plates were incubated at $28{ }^{\circ} \mathrm{C}$ for ten days. Isolates showed raised colonies on the surface of the agar regarded as sugar oxidizer.

\subsection{Numerical Taxonomy}

Phenotypic similarity among the test isolates were determined by UPGM linkage clustering analysis using STATISTCA program.

\section{Results and Discussion}

A total of 30 rhizobial isolates were recovered from root nodules of two cultivars of Cowpea plants (Vigna unguiculata L. Walp), collected from different areas of Fezzan. Each nodule was found to be occupied by two types of bacteria. One type has a colony similar to fast-growing rhizobia, producing large gum and developed colonies within 2-3 days. Whereas, the second type showed characteristics similar to slow-growing rhizobia like nodulate cowpea [34, 35] which produces raised shiny creamy small colonies (1 $\mathrm{mm}$ after more than 5 days of incubation) with regular edges and alkalinize the growth medium (Table 2). The authentication test and symbiotic traits (Table 1) showed that all slow-growing (30 isolates) were able to form symbiosis in pure culture when tested on their host and other test plants (F. albida and A. hypogaea). However, different in their effectiveness traits (Table 1), fast-growing isolates failed to nodulate any test plants including their host plants. These fast isolates were further investigated in sterile sand and their original soil, but no positive result was obtained (data not shown). Therefore, they were omitted from further study. F. albida was classified as a tree legume which has affinity to nodulate by slow-growing rhizobia [36] and $A$. hypogaea belong to the cowpea cross-nodulation group. However, rare reports indicated that legumes can nodulate by fast-growing rhizobia [33, 37]. Based on cultural and symbiotic characteristics, the test isolates seemed to be similar to slow-growing rhizobia and therefore, this result support the findings of other researchers in West Africa [25], South Africa, Ghana and Botswana [26]. Some reporters claimed occurrences of both slow and fast-growing rhizobia inside nodules of cowpea [20-22]. In this study, as mentioned above, the fast-growing isolates were unable to form symbiosis under the laboratory conditions. Such result was reported from nodules of tropical legumes including Libya and identified as Agrabacterim strains [38]. Thus, these isolates could be Agrabacterim or rhizobia lost their symbiotic genes [38]. Environmental stress and nutrient limitation are dominant in arid desert soils like Fezzan soils. Therefore, occurrence of both types of bacteria (slow and fast-growing bacteria) inside each nodule could also explained by fast-growing bacteria and could forms synergic association with slow-growing rhizobia or protect them from environmental stress in the soil. But further investigations at both ecological and molecular levels are needed before any conclusion can be drawn.

A numerical taxonomic analysis performed on 56 non-symbiotic characteristics in statica showed that at similarity level of $70 \%$, the isolates formed four distinct groups (G1, G2, G3 and G4) and two isolates remained separate. Group 4 is a large group which can be divided into two subgroups: subgroup $4 \mathrm{~A}$ and subgroup 4B (Fig. 2). The composition of each group is presented in Table 1, which also showed symbiotic traits with F. albida and A. hypogaea in addition to their original host (Vigna unguiculata). The physiological and biochemical characteristics are shown in Table 2.

Each of groups 1 and 2 consisted of two isolates from nodules of indigenous cowpea (Crowed pea cultivar) growing in distantly separated areas (Ghat and Marzuq). The former group (Group 1) seemed effectively 
Table 1 Symbiotic traits (cross -nodulation) and groups resulted from numerical analysis.

\begin{tabular}{|c|c|c|c|c|c|c|}
\hline \multirow{2}{*}{ Isolates } & \multirow{2}{*}{ Isolation area } & \multirow{2}{*}{ Cultivar } & \multirow{2}{*}{ Groups } & \multicolumn{3}{|c|}{ Symbiotic traits } \\
\hline & & & & V. unguiculata & F. albida & A. hypogea \\
\hline RV22 & Marzuq & Crowed pea (brown eye) & Separate & $\mathrm{E}$ & I & I \\
\hline RV4 & Ghat & Crowed pea (brown eye) & Separate & I & I & $\mathrm{E}$ \\
\hline RV28 & Marzuq & Crowed pea (brown eye) & Group 1 & $\mathrm{E}$ & I & $\mathrm{E}$ \\
\hline RV26 & Ghat & Crowed pea (brown eye) & Group 1 & $\mathrm{E}$ & I & $\mathrm{E}$ \\
\hline RV20 & Marzuq & Crowed pea (brown eye) & Group 2 & I & I & I \\
\hline RV21 & Ghat & Crowed pea (brown eye) & Group 2 & I & I & I \\
\hline RV25 & Marzuq & Crowed pea (brown eye) & Group 3 & I & I & I \\
\hline RV24 & Ghat & Crowed pea (brown eye) & Group 3 & I & I & I \\
\hline RV23 & Alshati & Crowed pea (brown eye) & Group 3 & I & I & I \\
\hline RV18 & Sebha & Crowed pea (brown eye) & Group 3 & $\mathrm{E}$ & I & I \\
\hline RV12 & Ghat & Crowed pea (brown eye) & Group 3 & $\mathrm{E}$ & $\mathrm{E}$ & $\mathrm{E}$ \\
\hline RV29 & Marzuq & Crowed pea (brown eye) & Subgroup 4A & I & I & $\mathrm{E}$ \\
\hline RV19 & Marzuq & Crowed pea (brown eye) & Subgroup 4A & I & I & I \\
\hline RV30 & Marzuq & Black eye & Subgroup 4A & $\mathrm{E}$ & I & $\mathrm{E}$ \\
\hline RV3 & Marzuq & Crowed pea (brown eye) & Subgroup 4A & I & I & I \\
\hline RV14 & Marzuq & Crowed pea (brown eye) & Subgroup 4A & I & I & I \\
\hline RV7 & Marzuq & Black eye & Subgroup 4A & $\mathrm{E}$ & I & $\mathrm{E}$ \\
\hline RV17 & Sebha & Crowed pea (brown eye) & Subgroup 4B & I & I & I \\
\hline RV27 & Marzuq & Crowed pea (brown eye) & Subgroup 4B & I & I & $\mathrm{E}$ \\
\hline RV16 & Ghat & Crowed pea (brown eye) & Subgroup 4B & $\mathrm{E}$ & I & $\mathrm{E}$ \\
\hline RV15 & Marzuq & Black eye & Subgroup 4B & I & I & I \\
\hline RV8 & Marzuq & Crowed pea (brown eye) & Subgroup 4B & I & I & $\mathrm{E}$ \\
\hline RV6 & Ghat & Crowed pea (brown eye) & Subgroup 4B & $\mathrm{E}$ & I & I \\
\hline RV2 & Ghat & Black eye & Subgroup 4B & I & I & I \\
\hline RV5 & Marzuq & Crowed pea (brown eye) & Subgroup 4B & I & I & $\mathrm{E}$ \\
\hline RV11 & Ghat & Crowed pea (brown eye) & Subgroup 4B & $\mathrm{E}$ & $\mathrm{E}$ & $\mathrm{E}$ \\
\hline RV10 & Sebha & Crowed pea (brown eye) & Subgroup 4B & I & I & I \\
\hline RV13 & Ghat & Crowed pea (brown eye) & Subgroup 4B & I & I & I \\
\hline RV9 & Sebha & Crowed pea (brown eye) & Subgroup4B & I & I & $\mathrm{E}$ \\
\hline RV1 & Sebha & Crowed pea (black eyed) & Subgroup 4B & I & I & I \\
\hline
\end{tabular}

$* \mathrm{I}=$ Ineffective, $\mathrm{E}=$ effective.

nodulated their hosts and Arachis plant, but ineffective with F. albida. Whereas, the members of second group (Group 2) formed ineffective symbiosis with all test plants including their hosts.

Group 3 included five isolates which fromed indigenous cowpea (crowed pea cultivar) from different areas: Ghat, Marzuq, Alshati and Sebha. With the exception of RV12 isolate, all the other group members appeared ineffective in nodules formation on the test plants (A. hypogaea and F. albida).

Group 4 is heterogonous group with respect to their effectiveness. Subgroup 4A consisted of six isolates from nodules of both cultivars grown in one area (Marzuq). All of them formed ineffective nodules on $F$. albida, but different in their symbiosis with their hosts and A. hypogaea.

Subgroup 4B included thirteen isolates form nodules formed on both cowpea cultivars collected from all 


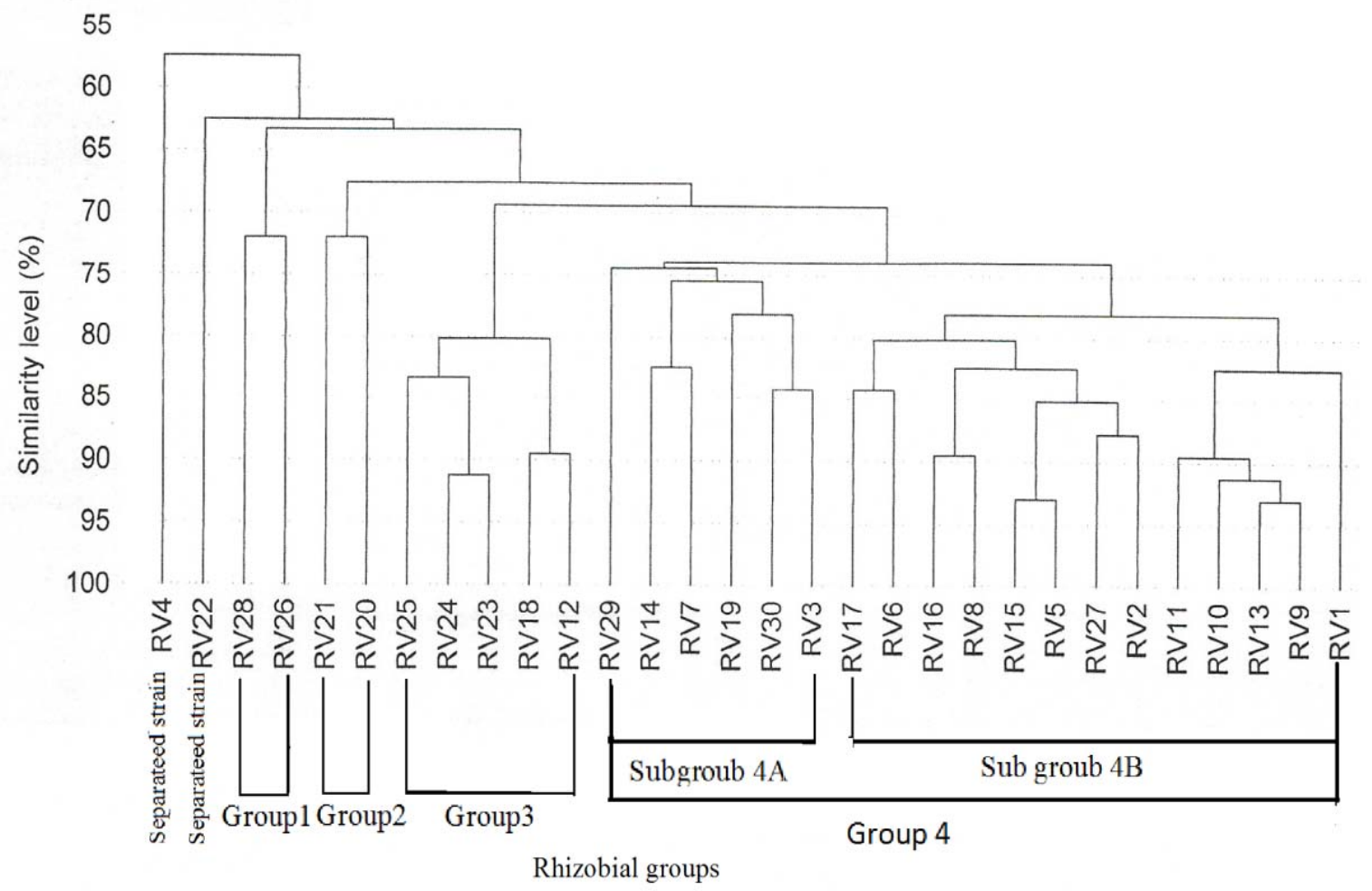

Fig. 2 Dendrogram showing the phenotypic relationship between the test isolates.

sites of study. As members of subgroup A, only one isolate (RV11) formed effective nodules on F. albida and the majority was ineffective with their hosts and $A$. hypogaea. Thus, these isolates formed group regardless of the isolation area or plant cultivar.

The non-grouped isolates RV22 and RV4 were from Marzuq and Ghat respectively. Both isolated from local cowpea cultivar nodules. The former isolate formed effective nodules only on its host. Whereas, the second gave the opposite reaction that seemed to form effective nodulate (A. hypogaea) and ineffective nodules (host plant and $F$. albida.) Some investigators $[39,40]$ classified cowpea isolates according to their effectiveness traits with its inoculation group. Effectiveness profiles on cowpea and siratro were similar. Whereas, lima bean and peanuts formed separate group. Some isolates were even unable to nodulate peanuts [40]. The results obtained here showed that with exception of separate isolates (RV22 and RV4) and some isolates in group 3 (one isolate) and group 4 (three isolates), they form effective symbiosis with leguminous plant (Cowpea and peanuts) and all isolates formed nodules on peanuts (A. hypogaea). Thus, the result reported here did not support those investigators $[39,40]$.

Physiological and biochemical tests have shown that the test isolates were diverse. The growth temperature for most Brayrhizobiumm spp. from different legumes is below $38{ }^{\circ} \mathrm{C}$ [4] in this study. The majority of the groups grew at $40{ }^{\circ} \mathrm{C}$, whereas, with the exception of group 3 , in addition to separate isolates, all other groups were unable to grow at $42{ }^{\circ} \mathrm{C}$. Growth of slow-growing rhizobia at temperature above $40{ }^{\circ} \mathrm{C}$ was previously reported for slow-growing isolates from Acacia cyanophylla grown in the region [33]. Temperatures higher than $40{ }^{\circ} \mathrm{C}$ are not uncommon at the tropical soils and in arid region of Libya. Thus, some of test isolates were similar to their counterparts from other legumes growing in Libya [33, 41], well adapted to their site of origin. The evaluation of in vitro tolerance to high temperatures may help in the selection of more stable strains to heat conditions [42]. 
Table 2 Results of physiological and biochemical tests for the groups formed by numerical analysis.

\begin{tabular}{|c|c|c|c|c|c|c|c|}
\hline \multirow{3}{*}{ Characteristics } & \multicolumn{7}{|c|}{ Groups and their reactions } \\
\hline & \multirow{2}{*}{$\begin{array}{l}\mathrm{G} 1 \\
\mathrm{n}=2\end{array}$} & \multirow{2}{*}{$\begin{array}{l}\mathrm{G} 2 \\
\mathrm{n}=2\end{array}$} & \multirow{2}{*}{$\begin{array}{l}\mathrm{G} 3 \\
\mathrm{n}=5\end{array}$} & \multicolumn{2}{|c|}{$\mathrm{G} 4 \mathrm{n}=19$} & \multirow[b]{2}{*}{ RV4 } & \multirow[b]{2}{*}{ RV22 } \\
\hline & & & & $\begin{array}{l}\mathrm{G} 4 \mathrm{~A} \\
\mathrm{n}=6\end{array}$ & $\begin{array}{l}\mathrm{G} \text { 4B } \\
\mathrm{n}=13\end{array}$ & & \\
\hline \multicolumn{8}{|l|}{ First colony formed } \\
\hline 1-5 days & - & - & - & - & - & - & - \\
\hline $6-10$ days & + & + & + & + & + & + & + \\
\hline Acid production & - & - & - & - & - & - & - \\
\hline Alkali production & + & + & + & + & + & + & + \\
\hline \multicolumn{8}{|l|}{ Growth at } \\
\hline $40{ }^{\circ} \mathrm{C}$ & + & (1) & + & (4) & (3) & + & + \\
\hline $42{ }^{\circ} \mathrm{C}$ & - & - & + & - & - & + & + \\
\hline \multicolumn{8}{|l|}{ Growth at $\mathrm{pH}$} \\
\hline pH 4 & + & - & - & (1) & (12) & + & + \\
\hline $\mathrm{pH} 5$ & + & (1) & - & $(2)$ & $(12)$ & + & + \\
\hline $\mathrm{pH} 6$ & + & + & + & $(5)$ & + & + & + \\
\hline $\mathrm{pH} 8$ & + & + & + & + & + & + & + \\
\hline pH 9 & + & + & + & $(5)$ & + & + & + \\
\hline $\mathrm{pH} 10$ & + & $(1)$ & + & (4) & + & + & + \\
\hline \multicolumn{8}{|c|}{ Heavy metals resistance (mg/L) } \\
\hline $100 \mathrm{CuCl}_{2} \cdot 2 \mathrm{H}_{2} \mathrm{O}$ & + & (1) & + & $(5)$ & + & - & + \\
\hline $100 \mathrm{AlCl}_{3} \cdot 6 \mathrm{H}_{2} \mathrm{O}$ & + & + & $(2)$ & + & $(8)$ & - & + \\
\hline $200 \mathrm{AlCl}_{3} \cdot 6 \mathrm{H}_{2} \mathrm{O}$ & + & + & - & (3) & (2) & - & + \\
\hline $300 \mathrm{AlCl}_{3} \cdot 6 \mathrm{H}_{2} \mathrm{O}$ & + & (1) & - & (3) & (2) & - & + \\
\hline $500 \mathrm{AlCl}_{3} \cdot 6 \mathrm{H}_{2} \mathrm{O}$ & - & - & - & - & - & - & + \\
\hline $20 \mathrm{CdCl}_{2} \cdot 2 \mathrm{H}_{2} \mathrm{O}$ & (1) & - & (4) & (4) & (11) & - & - \\
\hline $100 \mathrm{ZnCl}_{2}$ & + & + & + & $(5)$ & + & - & + \\
\hline $500 \mathrm{~Pb}\left(\mathrm{CH}_{3} \mathrm{COO}\right)_{2}$ & + & - & + & (5) & + & + & + \\
\hline $30 \mathrm{HgCl}_{2}$ & + & + & + & + & + & - & + \\
\hline $40 \mathrm{HgCl}_{2}$ & + & (1) & + & + & + & - & + \\
\hline $100 \mathrm{NiCl}_{2}$ & - & (1) & - & (3) & $(10)$ & - & - \\
\hline \multicolumn{8}{|c|}{ Antibiotic resistance $(\mu \mathrm{g})$} \\
\hline Colistin 10 & + & + & + & + & (11) & + & - \\
\hline Erythromycin 15 & + & - & - & (1) & (1) & - & - \\
\hline Chloramphenicol 10 & + & + & - & - & (4) & - & + \\
\hline Ampicillin 10 & + & - & - & (1) & (3) & + & - \\
\hline Penicillin 10 & + & + & (2) & (1) & (4) & - & - \\
\hline Rifampicin 5 & - & - & - & - & - & + & + \\
\hline Streptomycin 10 & (1) & (1) & - & - & - & - & - \\
\hline Vancomycin 5 & (1) & (1) & - & (2) & (1) & - & + \\
\hline Bacitracin 10 & + & (1) & (4) & + & (11) & - & - \\
\hline Tetracyclin 30 & - & - & (1) & - & - & - & + \\
\hline Nalidixic acid 30 & + & - & (1) & (1) & (11) & - & + \\
\hline Kanamycin 30 & (1) & - & (1) & - & (1) & - & - \\
\hline
\end{tabular}


Table 2 continued

\begin{tabular}{|c|c|c|c|c|c|c|c|}
\hline \multirow{3}{*}{ Characteristics } & \multicolumn{7}{|c|}{ Groups and their reactions } \\
\hline & \multirow{2}{*}{$\begin{array}{l}\mathrm{G} 1 \\
\mathrm{n}=2\end{array}$} & \multirow{2}{*}{$\begin{array}{l}\mathrm{G} 2 \\
\mathrm{n}=2\end{array}$} & \multirow{2}{*}{$\begin{array}{l}\text { G } 3 \\
n=5\end{array}$} & \multicolumn{2}{|c|}{$\mathrm{G} 4 \mathrm{n}=19$} & \multirow[b]{2}{*}{ RV4 } & \multirow[b]{2}{*}{ RV22 } \\
\hline & & & & $\begin{array}{l}\mathrm{G} 4 \mathrm{~A} \\
\mathrm{n}=6\end{array}$ & $\begin{array}{l}\mathrm{G} 4 \mathrm{~B} \\
\mathrm{n}=13\end{array}$ & & \\
\hline Polymycin 30 & - & + & (4) & + & + & + & + \\
\hline Gentamicin 10 & (1) & - & - & - & - & - & - \\
\hline \multicolumn{8}{|c|}{ Salinity tolerance $(\% \mathrm{NaCl})$} \\
\hline 0.5 & + & + & (4) & + & (12) & + & + \\
\hline 1 & + & + & (3) & + & $(10)$ & + & + \\
\hline 1.5 & (1) & + & $(2)$ & + & (8) & + & + \\
\hline 2 & (1) & + & (2) & + & (6) & + & + \\
\hline 2.5 & (1) & (1) & (2) & (4) & (6) & + & + \\
\hline 3 & (1) & - & (2) & (4) & (6) & - & + \\
\hline 4 & - & - & - & - & - & - & - \\
\hline Hydrolysis of urea & + & (1) & (3) & (5) & (8) & + & + \\
\hline \multicolumn{8}{|c|}{ Carbohydrate utilization } \\
\hline D-glucose & (1) & - & (4) & (5) & (2) & - & + \\
\hline D-fructose & + & (1) & (4) & (1) & - & + & - \\
\hline Glalactose & - & (1) & (4) & (3) & (2) & - & + \\
\hline Maltose & (1) & - & + & + & (7) & + & + \\
\hline Sucrose & - & (1) & + & (5) & (11) & + & + \\
\hline Lactose & - & (1) & + & (4) & (5) & - & - \\
\hline D-mannose & - & - & (4) & (1) & (5) & - & + \\
\hline Truloes & (1) & - & (1) & - & - & - & - \\
\hline Cellulose & - & - & (1) & - & - & + & + \\
\hline Starch & (1) & (1) & (3) & (1) & (5) & + & - \\
\hline Sorbitol & - & - & (4) & (1) & (1) & + & + \\
\hline D-fruttosol & - & (1) & + & - & (1) & + & + \\
\hline Inositol & + & - & (1) & (2) & (1) & - & + \\
\hline
\end{tabular}

* Numbers of isolates formed groups, numbers in brackets represent the number of isolates resist or utlize.

The $\mathrm{pH}$ range for all groups was 6.0-10 (Table 2). The majority of isolates formed $\mathrm{G} 1$, subgroup $\mathrm{G} 4 \mathrm{~B}$ and separate isolates (RV4 and RV22) were acid tolerant which grew at $\mathrm{pH}$ as low as $\mathrm{pH} 4$. Thus, these isolates seemed to be related in their tolerant to acidity to their counterparts from Vigna unguiculata growing in Zimbabwean soils [5]. Alkaline $\mathrm{pH}$ has little effect on growth of most isolates, most of them grew at $\mathrm{pH}$ as high as $\mathrm{pH} 10$. Tolerance to alkaline $\mathrm{pH}$ could be related to the calcareous and dry soils from which these isolates were isolated. However, some investigators found no correlation between the $\mathrm{pH}$ of the soil from which the organism was isolated and it is tolerant to different levels of $\mathrm{pH}$ in growth medium [43]. Bradyrhizobium strains native to tropical soils, grow at different $\mathrm{pH}$ levels and optimal growth occurs at $\mathrm{pH} 6.0$, indicating that they are adapted to slightly acidic conditions [44].

The results recorded in Table 2 show that the test isolates exhibited a wide diversity in its ability to grow in different concentrations of salts and heavy metals. Generally, most of the isolates formed groups seemed to be resistance to $\mathrm{HgCl}_{2}, \mathrm{CuCl}_{2}, \mathrm{ZnCl}_{2}, \mathrm{~Pb}\left(\mathrm{CH}_{3} \mathrm{COO}\right)_{2}$, $\mathrm{CdCl}_{2} \cdot \mathrm{H}_{2} \mathrm{O}$ and $\mathrm{AlCl}_{3} \cdot 6 \mathrm{H}_{2} \mathrm{O}$ at low concentrations (100-200 $\mu \mathrm{g} / \mathrm{mL})$. But aluminum at high concentration $(500 \mu \mathrm{g} / \mathrm{mL})$ seemed to have more effect on most test 

Grown in Arid Region of Libya (Fezzan)

isolates with exception of one isolate (RV22) which all inhibited by this metal. Moreover, the isolates formed groups 1 and 3 in addition to the separate isolates (RV4 and RV22) were also suppressed by $\mathrm{NiCl}_{2}$. In this study, some isolates were tolerant acidity but were not tolerant to aluminum at high concentration. Thus, tolerance to acidity is not always correlated to tolerance to aluminum.

Intrinsic resistance to antibiotics showed a general resistance to polymycin (93\%), colistin (90\%), bacitracin $(80 \%)$ and nalidixic acid $(53 \%)$. On the other hand, most of the test isolates were more sensitive to gentamicin (97\%), tetracyclin (93\%), streptomycin (93\%), rifampicin (93\%), kanamycin (90\%), erythromycin $(90 \%)$, vancomycin $(80 \%)$, ampicillin (77\%) and penicillin (56\%). Some authors related resistance to antibiotics to geographical origin. For example, rhizobia isolated from sonorant desert (North America) were found to be highly resistance to antibiotics and related the adaptability of these rhizobia to the desert environment where antibiotics-producing microorganisms such as actinomycetes [45]. In this study, most of the test isolates seemed to be sensitive to naturally occurring antibiotics. Therefore, the resistance to antibiotics and other environmental stresses is strain specific rather than geographical origin [46].

Rhizobia and bradyrhizobia strains vary in their tolerance to salinity. Fast-growing rhizobia are more salt-tolerant than strains of slow-growing rhizobia. In the present study, rhizobial isolates varied in their reaction to salinity in agar medium. With exception of one isolate in each of group 3 and sub group 4B, all isolates were able to grow in $0.5 \% \mathrm{NaCl}$, but differently responded to the level above that. Members of group 4 were distinguished in their tolerance to salinity, the majority grew at $2.5 \%-3 \%$, but none of the test isolates were able to grow at $4 \% \mathrm{NaCl}$. In this respect, members of this group are resembles fast-growing rhizobia and appeared to be similar to their counterparts from cowpea indigenous to
Zimbabwe [5]. With respect to nitrogen-fixation efficiency, indigenous cowpea and stress tolerance like extreme temperature and salinity, some members of group 3 (RV12 and RV18) and group 4 (RV6, RV7, RV16 and RV30), in addition to separated isolate (RV22), could be selected for field inoculation trial in order to use as inocula for cowpea in arid region of Libya.

With exception of few isolates in group 3 (two isolates), group 2 (one isolate) and group 4 (6 isolates), all isolates were able to use urea as a nitrogen source. Hydrolysis of urea as nitrogen source is a common among rhizobia [19].

The result of the carbohydrates test showed that there are remarkable differences among test isolates. Monosaccharides and sugar alcohols (D-glucose, D-fructose, galactose, sorbitol and inositol) were poorly utilized by most test isolates, whereas, disaccharides (sucrose and maltose) were assimilated by most of them. Thus, they are in line with what reported by others for chickpea rhizobia [47]. Few isolates in different groups were used starch as a carbon source, but with exception of separate isolates and one isolate in group 3, all other groups were failed to use cellulose. Poor assimilation of monosaccharides and disaccharides is feature of some slow-growing rhizobia and Azorhizobium [31, 48, 49]. However, some fast-growing isolates from woody legumes grown in Libya were as slow-growing rhizobia which unable to use disaccharides. Soils of Libyan desert are poor in organic carbon. Therefore, utilization of different carbon sources could give these isolates advantage to live and persist in soil.

\section{Conclusion}

Cowpea in arid region of Libya had the affinity to nodulate with slow-growing rhizobia. All the isolates seemed to be infective with A. hypogea and F. albida in addition to their host, but not all were efficient in their nitrogen-fixation. Stress tolerant isolates has been identified for inoculation trials to sustain soils 


\section{Symbiotic and Phenotypic Characteristics of Rhizobia Nodulaing Cowpea (Vigna Unguiculata L. Walp) Grown in Arid Region of Libya (Fezzan)}

and increase cowpea productivity in Fezzan. The distinguished four phenotypic groups formed could indicate the genetic diversity of the isolates and different species may present in soils of Fezzan. In general, site of isolation and plant cultivar appeared to have little effect on their distribution in Fezzan soils. Further molecular and ecological studies to determine the role of coexist of slow-growing rhizobia with fast-growing rhizobium like strains inside each nodule and the relationship between these isolates and established rhizobial strains in different genera are needed.

\section{Acknowledgments}

The authors kindly thank Dr. abdalla Mohamed Adda for his support and Massouda Omar Abulkasem Khalifa for her assistance during preparation of this work.

\section{References}

[1] F.A.O. 2003. "Statistical Databases Provisional. Agricultural Production Data." Food and Agricultural Organization of the United Nations. Accessed August 30, 2004. http//www.fao.org.

[2] Woomer, P. L. 2010. Biological Nitrogen Fixation and Grain Legume Enterprise. Guidelines for $\mathrm{N}_{2}$ Africa Master Farmers. Nairobi: Tropical Soil Biology and Fertility.

[3] Graham, P. H., Sadowsky, M. J., Keiser, H. H., Barnet, Y. M., Bradlely, R. S., and Cooper, J. E. et al. 1991. "Propossed Minimal Standards for the Description of New Genera and Species of Root and Stem Nodulation Bacteria.” Int. J. Syst. Bacteriol 41: 582-587.

[4] Zhang, X., Harper, R., Karsisto, M., and Lindström, K. 1991. "Diversity of Rhizobium Bacteria Isolated from the Root Nodules of Leguminous Trees." Int. J. Syst. Bacteriol 53: 104-113.

[5] Mpepereki, S., Kakonese, F., and Wollum, A. G. 1997. "Physiological Characterization of Indigenous Rhizobia Nodulating Vigna Ungu-iculata in Zimbabwean Soils." Symbiosis 22: 275-292.

[6] Odee, D. W., Sutherland, J. M., Makatiani, E. T., McInroy, S. G., and Sprent, J. I. 1997. "Phenotypic Characteristics and Composition of Rhizobia Associated with Woody Legumes Growing in Diverse Kenyan Conditions." Plant and Soil 188: 65-75.

[7] Zahran, H. H., Abdel-Fattah, M., Yasser, M. M.,
Mahmoud, A. M., and Bedmar, E. J. 2012. "Diversity and Environmental Stress Responses of Rhizobial Bacteria from Egyptian Grain Legumes." Australian Journal of Basic and Applied Sciences 6 (10): 571-583.

[8] Jordan, D. C. 1982. "Transfer of Rhizobium Japonicum Buchanan 1980 to Bradyrhizobium Gen. a Genus of Slow-Growing Root Nodule Bacteria from Leguminous Plants." Int. J. Syst. Bacteriol 32: 136-139.

[9] Casida, E. J. 1982. "Ensifer Adhaerens Gen. Nov. Sp. Nov. a Bacterial Predator of Bacteria in Soil." Int. J. Syst. Bacteriol 32 (3): 339-345.

[10] Chen, W. X., Yan, G. H., and Li, J. H. 1988. "Numerical Taxonomic Study of Fast-Growing Soybeans Rhizobia and Proposal the Rhizobium Fredii Assigned to Sinorhizobium Gen..” Int. J. Syst. Bacteriol 38: 392-397.

[11] Jarvis, B. D. W., Van, Berkum, P., Chen, W. X., Nour, S. M., Fernandez, M. P., and Cleyet-Marel, J. C. et al. 1997. "Transfer of Rhizobiumloti, Rhizobiumhuakuii, Rhizobiumciceri, Rhizobiummediterraneum and Rhizobiumtianshanense to Mesorhizobium Gen.." Int. J. Syst. Bacteriol 47: 895-898.

[12] De, Lajudie, P., Laurent-Fulele, E., Willems, A., Torck, U., Coopman, R., and Collins, M. D. et al. 1998. "Allorhizobium Undicola Gen. Nov. Sp. Nov. Nitrogen-Fixing Bacteria That Efficiently Nodulate Neptunia Natans in Senegal." Int. J. Syst. Bacteriol 48: 1277-1290.

[13] Dreyfus, B., Garcia, J. L., and Gillis, M. 1988. "Characterization of Azorhizobium Caulinodans Gen. Nov. Sp. Nov. a Stem Nodulating Nitrogen-Fixing Bacterium Isolated from Sesbania Rostrata." Int J. Syst. Bacteriol 38: 89-98.

[14] Patt, T. E., Hanson, R. S., and Cole, G. C. 1976. "Methyobacterium, a New Genus of Facultatively Methylotrophic Bacteria." Int. Syst. Evol. Microbiol 26: 226-229.

[15] Rivas, R., Willems, A., Subba-Rao, N. S., Mateos, P. F., Dazzo, F. B., and Kroppenstedt, R. M. et al. 2003. "Description of Devosia Neptuniae Sp. Nov. That Nodulates and Fixes Nitrogen in Symbiosis with Neptunia Natans, an Aquatic Legume from India." Syst. Appl. Microbiol 26: 47-53.

[16] Chen, W. M., Laevens, S., Lee, T. M., Coenye, T., De Vos, P., and Mergeay, M. et al. 2001. "Ralstonia Taiwanensis Sp. Nov. Isolated from Nodules of Mimosa Species and Sputum of a Cystic Fibrosis Patient." Int. J. Syst. Evol. Microbiol 51: 1729-1735.

[17] Lin, D. X., Wang, E. T., Tang, H., Han, T. X., He, Y. R., and Guan, S. H. et al. 2008. "Shinella Kummerowiae Sp. Nov. a Novel Symbiotic Bacterium Isolated from Root Nodule of the Herbal Legume Kummerowia Stipulacea." Int. J. Syst. Evol. Microbiol 58: 1409-1413. 
[18] Allen, O. N., and Allen, E. K. 1981. The Leguminosae: A Source Book of Characteristics, Uses and Nodulation. London: University of Wisconsin Press, Madison, WI/MacMillan Publishing.

[19] Jordan, D. C. 1984. "Family III. Rhizobaceae Conn 1938." In Bergy Manual of Systematic Bacteriology, Edited by Krieg, N. R., and Holt, J. G. Baltimore: Williams and Wilkins.

[20] Mpepereki, S., Wollum, A. G., and Makonese, F. 1996. "Diversity in Symbiotic Specificity of Cowpea Rhizobia Indigenous to Zimbabwean Soil." Plant \& Soil 186: 167-171.

[21] Martins, L. M. V., Neves, M. C. P., and Rumjanek, N. G. 1997. "Growth Characteristics and Symbiotic Efficiency of Rhizobia Isolated from Cowpea Nodules of the Northeast Region of Brazil." Soil Biol. Biochem 29: 1005-1010.

[22] Zhang, W. T., Yang, J. K., Yuan, T. Y., and Zhou, J. C. 2007. "Genetic Diversity and Phylogeny of Indigenous Rhizobia from Cowpea (Vigna Unguiculata L. Walp)." Biology and Fertility of Soils 44: 201-210.

[23] Steenkamp, E. T., Stepkowski, T., Przymusiak, A., Botha, W. J., and Law, I. J. 2008. "Cowpea and Peanut in Southern Africa are Nodulated by Diverse Bradyrhizobium Strains Harbouring Genes That Belong to the Large Pantropical Clade Common in Africa." Mol-Phylogenet Evol. 48: 1131-1144.

[24] Silva, F. V., Araújo, J. L., and Rumjanek, N. G. 2012. "Genetic Diversity of Rhizobia Isolates from Amazon Soils Using Cowpea (Vigna Unguiculata L. Walp) As Trap Plant.” Braz. J. Microbiol 43 (2): 682-691.

[25] Krasva-Wade, T., Ndoye, I., Braconnier, S., Sarr, B., Delajudie, P., and Neyra, M. 2003. "Diversity of Indigenous Bradyrhizobia Associated with Three Cowpea Cultivars (Vigna Unguiculata L. Walp), Grown under Limited and Favorable Water Conditions in Senegal (West Africa)." African Journal of Biotechnology 2 (1): 13-22.

[26] Pule-Meulenberg, F., and Dakora, F. D. 2009. “Assessing the Symbiotic Dependency of Grain and Tree Legumes in $\mathrm{N}_{2}$ Fixation for Their Nnutrition in Five Agroecological Zones of Botswana." Symbiosis 48: 68-77.

[27] Law, I. J., Botha, W. F., Majaule, U. C., and Phalane, F. L. 2007. "Symbiotic and Genomic Diversity of 'Cowpea' Bradyrhizobia from Soils in Botswana and South Africa." Biol. Fert. Soils 43: 653-663.

[28] Sarr, P. S., Yamakawa, T., Saeki, Y., and Guisse, A. 2011. "Phylogenetic Diversity of Indigenous Cowpea Bradyrhizobia from Soils in Japan Based on Sequence Analysis of the 16S-23S rRNA Internal Transcribed Spacer (ITS) Region.” Syst. Appl. Microbiol 34 (4): 285-92.
[29] Sharaf, A. T. 1971. Geography of Libya, 2nd Edition. Alexandria: Almaarif Press.

[30] Vincent, J. M. 1970. A Manual for the Practical Study of Root Nodule Bacteria. IBP Handbook. England: Blackwell, Oxford.

[31] Lajudie, P., Willems, A., Pot, B., Dewettinck, D., Amestrojuan, G., and Nyrra, M. et al. 1994. "Polyphasic Taxonomy of Rhizobia: Emendation of the Genus Sinorhizobium and Description of Sinorhizobium Meliloti Comb.” Int. J. Syst. Bacteriol 44: 715-733.

[32] Barnet, Y. M., and Catt, P. C. 1991. "Distrbution and Characteristics of Root-Nodule Bacteria Isolated from Australian Acacia Spp." Plant Soil 135: 109-120.

[33] Mohamed, S. H., Smouni, A., Neyra, M., Kharchaf, D., and Filali Maltouf, A. 2000. "Phenotypic Characteristics of Root-Nodulating Bacteria Isolated from Acacia Spp. Growing in Libya." Plant and Soil 224: 171-183.

[34] Florentino, L. A., Sousa, P. M., Silva, J. S., Silva, K. B., Moreira, F. M. S. 2010. "Diversity and Efficiency of Bradyrhizobium Strains Isolated from Soil Samples Collected from Around Sesbania Virgata Roots Using Cowpea as Trap Species." Rev. Bras. Cienc. Solo 34: 1113-1123.

[35] Zilli, J. E., Valisheski, R. R., Freire-Filho, F. R., Neves, M. C. P., Rumjanek, N. G. 2004. "Assessment of Cowpea Rhizobium Diversity in Cerrado Areas of Northeastern Brazil." Braz. J. Microbiol 35: 281-287.

[36] Dreyfus, B. L., and Demmergues, Y. R. 1981. "Nodulation of Acacia Species by Fast and Slow Growing Tropical Strains of Rhizobium." Appl. Environ. Microbiol 41: 97-99.

[37] Lyra, M. C. P., Freitas, A. D. S., Silva, T. A., and Santos, C. E. R. S. 2013. "Phenotypic and Molecular Characteristics of Rhizobia Isolated from Nodules of Peanut (Arachis Hypogaea L.) Growing in Brazilian Spodosols.” Afr. J. Biotechnol 12 (17): 2147-2156.

[38] Lajudie, P., Willems, A., Nick, G., Mohamed, S. H., Torck, U., and Coopman, R. et al. 1999. "Characterization of Agrobacterium Bv. Strains Isolated from Nodules of Tropical Legumes." Syst. Appl. Microbiol 22: 119-132.

[39] Burton, J. C. 1979. Rhizobium Species. New York: Academic Press Inc..

[40] Thies, J. E., Singleton, P. W., and Bohlool, B. B. 1991. "Sub-groups of the Cowpea Miscellany: Symbiotic Specificity within Bradyrhizobium Spp. for Vigna Unguiculata, Phaseolus Lunatus, Arachishypogaea and Macroptilium Atropurpureum." Appl. Environ. Microbiol 57: 1540-1545.

[41] Khalifa1, M. O. A., Babiker, N. N., and Mohamed, S. H. 2014. "Physiological Characteristics of Rhizobia Isolated from Retamaraetam (Forsk) and Lupinus Various (L.) 


\section{Symbiotic and Phenotypic Characteristics of Rhizobia Nodulaing Cowpea (Vigna Unguiculata L. Walp) Grown in Arid Region of Libya (Fezzan)}

Indigenous to Libyan Desert.” J. Environ. Sci. and Eng. B 3: 1045-1053.

[42] Xavier, G. R., Martins, L. M., Rumjanek, N. G., and Neves, M. C. P. 2007. "Tolerance of Cowpea Rhizobia to Salinity and Temperature in Vitro Condition." Caatinga 20: $1-9$

[43] Ruiz-Diez, B., Fajardo, S., Puertas-Mejia, M. A., Felipe, M. D. R., and Fernandez-Pascual, M. 2009. "Stress Tolerance, Genetic Analysis and Symbiotic Properties of Root-Nodulating Bacteria Isolated from Mediterranean Leguminous Shrubs in Central Spain.” Arch. Microbiol 191: 35-46.

[44] Miguel, D. L., and Moreira, F. M. S. 2001. "Influence of Medium and Peat $\mathrm{pH}$ on the Behavior of Bradyrhizobium Strains.” R. Bras. Ci. Solo 25: 873-883.

[45] Shishido, M., and Pepper, I. L. 1991. "Evaluation of Rhizobium Meliloti Strains Indigenous to Sonoran Desert Soils by Plasmid Profile and Intrinsic Antibiotic
Resistance." In The Rhizosphere and Plant Growth, edited by Keister, D. L., and Cregarn Kluwer, P. B. Boston: Academic Publishers.

[46] Graham, P. H. 1992. "Stress Tolerance in Rhizobium and Bradyrhizobium and Inoculation under Adverse Soil Conditions." Can. J. Microbil 38: 475-484.

[47] Maâtallah, J., Berraho, E., Sanjuan, J., and Lluch, C. 2002. "Phenotypic Characterization of Rhizobia Isolated from Chickpea (Cicer Arietinum) Growing in Moroccan." Soils Agronomie 22: 321-329.

[48] Stowers, M. D., and Elkan G. H. 1984. "Growth and Nutritional Characteristics of Cowpea Rhizobia." Plant and Soil 80: 191-200.

[49] Eaglesham, A. R. J., Stowers, M. D., Maina, M. L., Goldman, B. J., Sinclair, M. J., and Ayanaba, A. 1987. "Physiological and Biochemical Aspects of Diversity of Bradyrhizobium Spp. (Vigna) from Three West African Soils." Soil Biol. Biochem. 19: 575-581. 